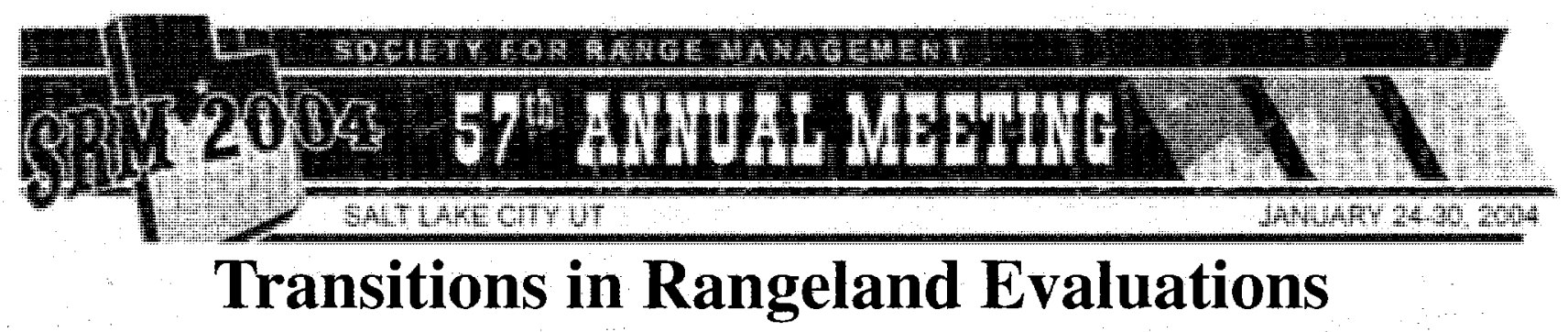

\title{
A review of the major transitions in rangeland evaluations during the last 25 years and speculation about future evaluations.
}

\author{
By David A. Pyke and Jeffrey E. Herrick
}

Concepts and practices of rangeland evaluation have evolved with time. Twenty-five years ago, if evaluations even were mentioned in textbooks, the focus was on upland areas, ignoring wetlands and any transitional areas associated with streams and lakes. Evaluations emphasized inventories of biological and physical characteristics of upland units, and determined status and trends of these characteristics as a surrogate for the status and trends of rangelands as a whole. Evaluations of rangeland status, referred to as rangeland condition, relied heavily on measurements of the variety of vascular plants present, and a comparison of these measurements against a standard amount or proportion of these plants.

In recent times, we continue efforts to determine the status of rangelands and evaluate any changes in a plant community relative to a standard. However, the traditional approaches no longer meet the needs of rangeland managers. New tools are being developed to address three issues: (1) increased demand for indicators that reflect ecosystem function and that are relevant to multiple uses and values in upland systems, (2) increased importance of wetland, riparian and aquatic communities as integral parts of rangeland ecosystems, and (3) the need for quantitative, consistent national and regional evaluations that effectively address both of the first two issues.

In addition, we are increasing our understanding of the importance of spatial relationships among different land units in both upland and riparian ecosystems. We now recognize the need for evaluations that look beyond local management units and single dominant uses, like livestock grazing. We think now about watersheds, basins, and regions, as well as fish and wildlife populations that co-occur with livestock on our rangelands.

New technologies in remote sensing allow us to view land changes over much larger areas than in the past. Our increased understanding of the importance of linkages among the living components (all of the interacting organisms) and non-living components (e.g., soils, air, and water) of rangelands and processes occurring within rangelands (e.g., nutrient and water cycling as well as energy flow) has led to the development of new approaches for evaluating rangelands. We even occasionally try to include social, economic, and legal aspects of rangelands in evaluations.

This article is an opportunity to review the major transitions in rangeland evaluations during the last 25 years and realize how much change has occurred in our approaches. It also provides an opportunity to speculate about the future evaluations.

\section{Step Back in Time}

A specific year to pick is a bit arbitrary, but if we look back 25 years to 1978 , we find ourselves in the age of rangeland inventory. This was a period of about 20 to 30 years devoted to the systematic acquisition and analysis of resource information needed for planning and management of rangelands. Prior to that period, livestock carrying capacities were being calculated and livestock stocking levels were being adjusted, but we often knew little about the potential of the land to support varieties of plants and animals.

By 1978, some of today's major players in rangeland evaluation were fresh out of college, taught by 
the experts and well read in the latest textbooks. The third addition of Range Management by Stoddard, Smith and Box devoted a chapter to inventory and evaluation. Rangeland Management by Heady stated that a complete textbook should be devoted to the subject of inventory and planning.

In a series of acts during this period, the U.S. Congress mandated that inventories of natural resources be conducted by federal agencies. The Congress passed the Resources Planning Act of 1974 (U.S. Forest Service), the Federal Land Policy and Management Act of 1976 (Bureau of Land Management), and the Soil and Water Resources Conservation Act of 1977 (Soil Conservation Service). These acts all required inventories of the natural resources in the nation. To meet these requirements, the Bureau of Land Management (BLM) initiated the Soil Vegetation Inventory Method (SVIM), the U.S. Forest Service (USFS) identified and mapped habitat types and the Soil Conservation Service (SCS now Natural Resource Conservation Service, NRCS) implemented the National Resources Inventory on non-federal lands including rangelands. The SCS, according to the 1976 National Range Handbook, continued to describe soils using standard survey methods and to identify range sites, lands with soils and climates that can support a certain set of plant species and can produce an anticipated amount of biomass. Eventually, the BLM abandoned the SVIM in favor of the range sites of the SCS.

These inventories laid the foundation for measuring rangeland condition and trend. Rangeland condition is an indicator of the current status of a rangeland location, whereas trend indicates the changes in that status over time. All agencies used variations of a similar approach to estimate condition and trend. This approach was proposed by E. J. Dyksterhuis in 1949 and relied on an understanding of livestock preferences for plant species and on understanding the nature of plant community development (plant succession) during periods of livestock grazing and after periods when livestock grazing was removed from the land.

In some cases, current plant communities were compared to an expected climax or late-successional community (the communities that would develop with only minimal disturbances). In other cases, the current community was compared to a hypothetical proportion of plants that tend to decrease, increase or invade following livestock grazing, or to a proportion of desirable, intermediately desirable and undesirable plants for livestock. The proportions allowed managers to quantify rangeland condition and classify the land into condition classes (excellent, good, fair, and poor) or successional stages (potential natural community, or late-, mid- and early-seral community).

This focus on plant community development was based on the notion that plant communities developed in predictable ways through time, resulting in relatively self-perpetuating communities when disturbances were minimal. This succession-based theory assumed four possible outcomes as impacts of livestock grazing increased in severity. First, desirable plants, or those sensitive to livestock impacts, would decrease in dominance as livestock grazing impacts became more severe. Second, undesirable native or grazing-tolerant plants would increase in dominance to a point and then eventually decrease with increasing livestock impacts. Third, invasive plants would colonize and become dominant when severe livestock impacts reduced the dominance of native plants. Lastly, if livestock grazing impacts were relaxed, then changes in plant communities caused by livestock would be reversed.

Managers measured plant dominance for these condition classifications using either plant cover or biomass. Managers were expected to reduce livestock numbers or adjust grazing seasons when rangeland conditions declined. Based on successional theories, the vegetation was expected to respond in a favorable fashion (Fig. 1). However, even in 1975 when Range Management $3^{\text {rd }}$ Edition was published, the authors questioned the underlying assumptions that climax or late-successional communities should be the ultimate goal and that community succession would allow rangeland condition to improve coincident with adjustments in livestock management.

The focus on rangeland condition also required classification of rangelands into categories for purposes of communication, comparison, and generalization. Rangeland units were placed in discrete plant groupings using different methods in the different agencies. The USFS used a vegetation community type or habitat type approach. This technique was an approach developed by Daubenmire, 


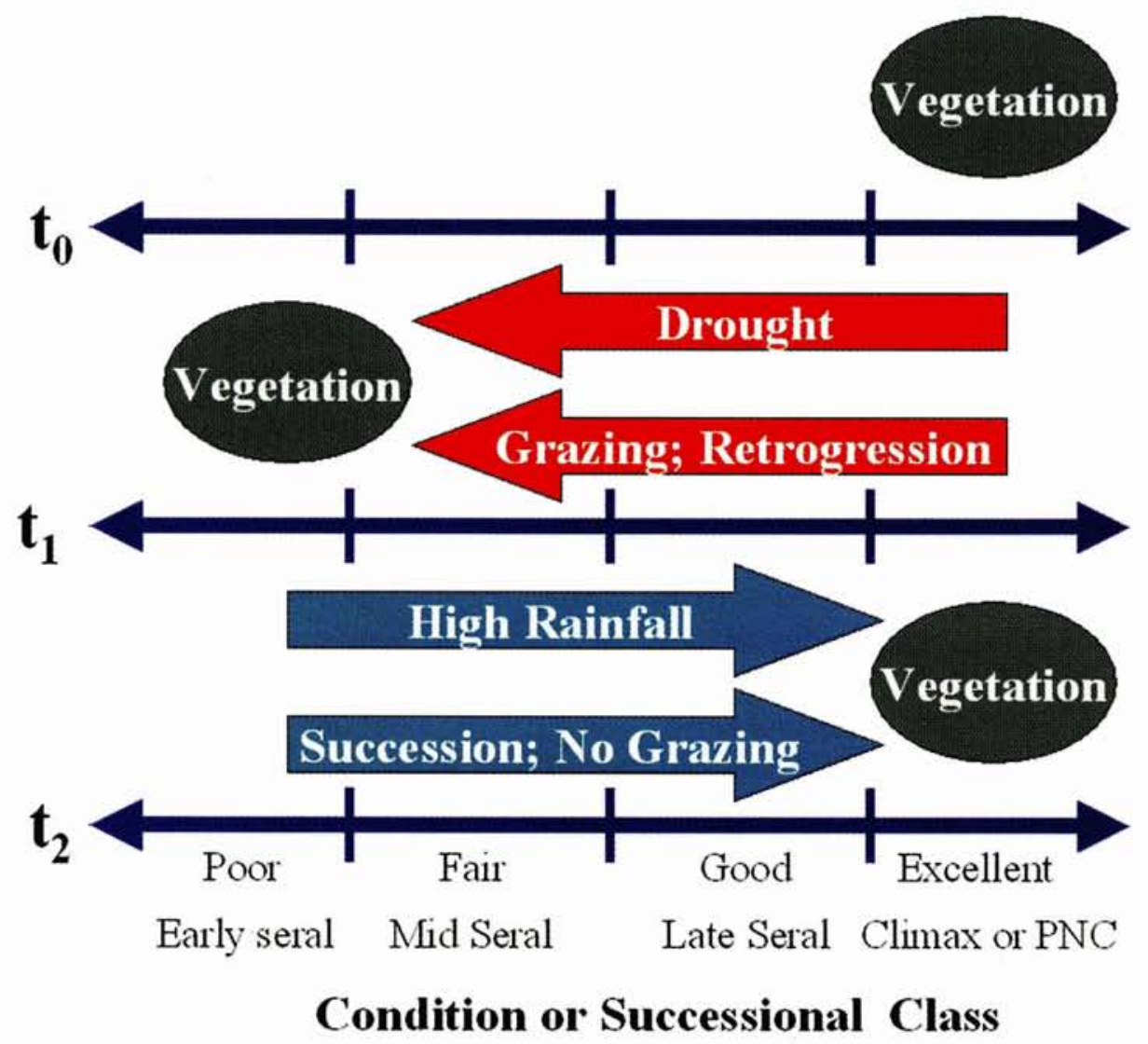

Fig. 1. Representation of the plant succession assumptions behind rangeland condition evaluations (after Westoby, Walker and Noy Meir 1989). Increasing time of succession is represented by $t_{0}, t_{1}$, and $t_{2}$.

who described forest and rangeland vegetation communities in Washington State. He was an advocate for the concept of the climax plant community and for the ability of managers to identify discrete assemblages of plants for a given soil and climate termed plant associations.

Other land management agencies in the U.S.A. ultimately followed the range site concept of the SCS. The range site concept was later broadened and renamed as ecological sites. The NRCS in 1997 defined both range sites and ecological sites as a kind of land with specific physical characteristics that differs from other kinds of land in its ability to produce distinctive kinds and amounts of vegetation in response to management. Generally, a soil series has one unique ecological site that is correlated to it, whereas an ecological or range site often includes several potential soil series within it. Habitat types and range or ecological sites are similar in concept. The USFS eventually modified its habitat type approach to ecological types so that it became similar to ecological sites.

During the age of inventories, concerns about the effects of livestock grazing on plant communities were driving much of the efforts to evaluate rangelands. It therefore was essential to develop a system for describing intensities of animal utilization of plants. Utilization commonly was defined as a percentage of the current forage production consumed or destroyed by all grazing animals during a year. Net forage production is estimated directly by measuring biomass or weight and indirectly by a variety of estimation techniques including height-to-weight ratios and stem counts. The term utilization refers commonly to a single species or to a management unit. It is more difficult to measure and interpret utilization for a management unit than a single species. 
During this time, the key species concept was applied to utilization. As Stoddard, Smith and Box in their 1975 textbook pointed out, this concept required land managers to select up to four plant species to monitor. Those selected needed to be of sufficient abundance and palatability to livestock to justify their use as an indicator of the degree of utilization for the management unit. These species constituted the majority of the forage for livestock, and the underlying assumption was that monitoring the use of these species and adjusting livestock management to achieve their appropriate degree of use would ensure appropriate use of the whole management unit.

There were practical benefits to this approach, but there were obvious weaknesses. This concept tended to sacrifice less abundant, yet highly preferred species on the unit. This occurred because livestock were allowed to graze until utilization met the desired amount for the key species, however highly preferred species would be sacrificed if they were less abundant because they would experience overuse before the key species achieved its level of proper use. Because many rangelands in the western U.S. were still recovering from intensive grazing use during the early 1900's, some less-abundant and highly palatable species may have been extirpated or held in low proportions in these rangelands as a result of managers applying this concept.

During the 1970's and early 1980's ecologists increasingly recognized the importance of biological diversity, including the concepts of both species richness (numbers of species) and evenness (proportional distribution of cover or weight among species). Rangeland management textbooks indirectly referred to diversity as "plant composition" and only emphasized its relationship to determining rangeland condition. Since rangeland condition was heavily weighted toward dominant plant species or species preferred by livestock, the monitoring and maintenance of less dominant species, as would be done using diversity measures of species richness and evenness, was minimized.

Our 25-year historical perspective helps us realize that evaluations of rangeland focused almost exclusively on the impacts that livestock made on upland vegetation and on how vegetation responded to adjustments in livestock management. Our evaluations assumed that upland vegetation was an ade- quate indicator for all components of a rangeland ecosystem. Did upland communities adequately describe riparian communities? Were we failing to evaluate some important aspects of our rangeland ecosystems or the importance of spatial relationships among landscape and management units? Had we misinterpreted or ignored some geological, physical and ecological processes, such as soil development, hydrology, water and nutrient cycles, and energy flow, in these rangeland ecosystems? If we were to include ecosystem processes, how should we evaluate these processes?

\section{Years of Change}

Upland Systems - An ongoing debate continues about the use of traditional measures of rangeland condition and trend for upland areas. Rangeland managers have noted international examples of the failure of the rangeland succession model used in the traditional condition classification. Often the failures were recorded in arid and semiarid environments. The removal of livestock grazing alone was frequently insufficient to allow vegetation succession to proceed as predicted within typical management time frames. In 1989, Westoby and coauthors outlined many of the flaws of the traditional rangeland succession model and they offered an alternative succession model, the state-and-transition model. In this model, states were vegetation communities and transitions were natural or management induced actions that shift vegetation composition to form a new vegetation community.

This model continues to be refined and is currently being applied in revisions of ecological sites by the NRCS in the U.S.A. The new ecological site descriptions incorporate the concept of thresholds, unidirectional transitions, which were introduced to the rangeland community by Friedel and Laycock, both in 1991. Stringham and coauthors and Bestelmeyer and coauthors both in 2003 described the current approach being used in new ecological site descriptions, while Briske and coauthors in 2003 provided a summary of key limitations. Figure 2 provides a simplified diagram of this approach.

Dissatisfaction among scientists and managers alike with the rangeland succession model for determining rangeland condition brought proposals for new methods of evaluating rangeland status. In 1995, a task group of the Society for Range 


\section{Reference State Shrub - Native Perennial Grass}

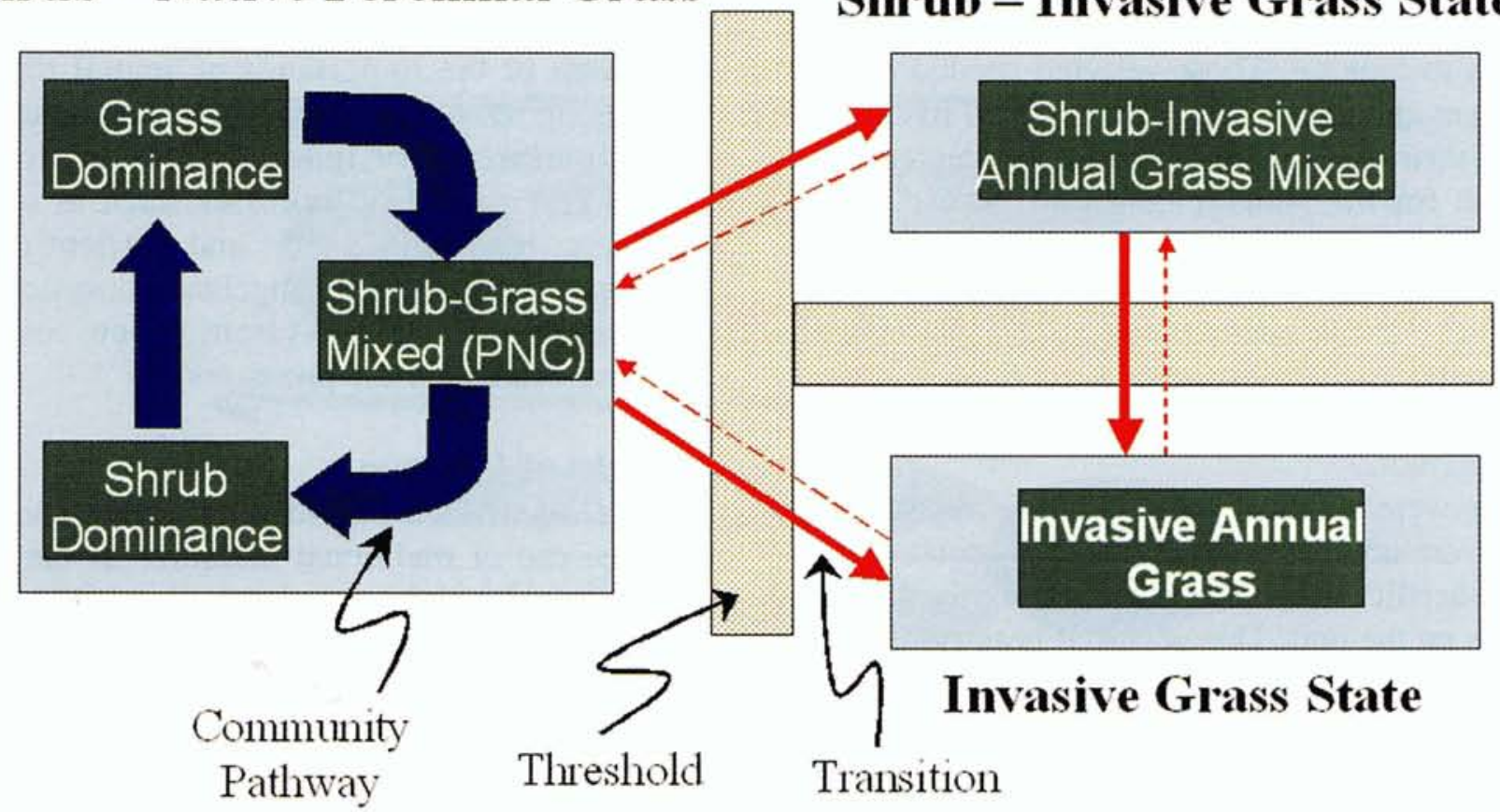

Fig. 2. State, transition and threshold concept for a hypothetical shrub grassland ecological site Red solid and dashed arrows between states indicate a likely unidirectional threshold between these states. (after Stringham, Krueger and Shaver 2003).

Management proposed an integrated vegetation and soil-based approach that could determine status using a quantitative measure called, a "site conservation rating." The group proposed that each ecological site has what they termed a "site conservation threshold." This threshold is a range of site conservation ratings below which the kind, amount and distribution of vegetation is insufficient to protect the site from accelerated soil erosion. They advocated that ecological site descriptions prepared by the NRCS should define the array of plant communities that could occur above this threshold and managers should strive in their practices to produce or maintain one of these communities. Unfortunately, these thresholds remain largely theoretical and require additional research to define their values.

The use of indicators in rangeland evaluation has been a recurrent theme. The trend has been to move from one or two indicators to a suite of indicators. In one of the proposals, the National Research Council's 1994 publication of Rangeland Health,
New Methods to Classify, Inventory, and Monitor Rangelands advocated an approach based on a series of indicators to describe three criteria of rangeland status. Their criteria were soil stability and watershed function, nutrient cycles and energy flow, and the presence of recovery mechanisms. They recognized that many of their indicators would require research before reliable and affordable techniques could be found for quantitative measurements, so they advocated an initial qualitative check-sheet approach for evaluations.

Several approaches are being developed simultaneously in the U.S.A. and Australia that are based on concepts similar to the National Research Council. Pellant and coauthors in 2000 developed a qualitative technique called Interpreting Indicators of Rangeland Health that currently is being applied by the BLM and NRCS. This approach uses 17 indicators to rate a site in three attributes or criteria, soil and site stability, hydrologic function, and biotic integrity. Soil and site stability describes a location's ability to limit soil erosion to the normal 
amount expected for the location. Hydrologic function is the ability of the location to capture, store and safely release water while biotic integrity is the capacity of a location to resist the loss of biological functions and be resilient enough for the biological organisms to recover from disturbances. Thus instead of one overall rating of rangeland status, a manager obtains three separate ratings giving a more specific description of the status of the land than a single rating. Pyke and coauthors in 2002 modified the standard for comparison by de-emphasizing the need for reference areas and advocating the reliance on a written description of the range of values expected for each indicator on an ecological site. They also proposed a series of quantitative techniques that could be used to monitor many of the indicators, but applications of these techniques have not been formally reported.

In Australia, Tongway in 1994 and his coworkers in 2000 developed landscape and ecosystem analyses for evaluating rangelands. Similar to several of the U.S.A. approaches, they have elected to use the criteria (they call them indices) and indicator approach. They advocate three indices, stability, infiltration, and nutrient cycling. Their approach uses quantitative measurements to arrive at an evaluation of status.

Riparian and Aquatic Systems - The rangeland management profession began its discovery of rangeland ecosystem diversity by examining river systems in rangelands. After World War II, water management was focused on increasing the quantity and reliability of water for human uses, including irrigation, electricity production, recreational opportunities and human consumption.

Chaney and coauthors in 1993 wrote a document for ranchers on the Clean Water Act that mentioned past management recommendations for riparian areas. In that document, they reported that removal of riparian plants to reduce the loss of water to the atmosphere through transpiration had been a common practice on rangelands. This was even done under the guise of improving fish habitat. Therefore, declines in riparian vegetation associated with livestock grazing were often not recognized as a problem until the 1980's because some of these other practices, conceptually and practically, kept our attention away from livestock effects.

We began to notice stream systems that were sim- plified, down-cut and channelized and we documented the historic complexity of many of these systems. Water tables had dropped, wetlands became more arid, and upland plants were invading these wetlands. Many of our rangeland watersheds were no longer capturing, storing and releasing water continuously over time. Some perennial streams were only flowing during a portion of the year.

These changes prompted studies which began to show that both upland and riparian plant communities were important in maintaining stream flows, fish habitat, water quality and quantity. Elmore and Kauffman in 1994 reported livestock had contributed to the decline in riparian systems and through modifying management riparian systems could be improved. These observations and studies led to an amendment to the Clean Water Act that recognized when inappropriate land management, including livestock grazing, was applied to riparian systems, they could lead to non-point sources of water pollution. Thus, techniques were developed to evaluate the status of riparian ecosystems.

Some quantitative methods evaluated both physical and vegetation characteristics of streams. Physical aspects included monitoring shapes of stream channels over time. Harrellson and coauthors in 1994 discussed a series of quantitative methods that can be applied to river systems for monitoring. They recommended that managers establish permanent cross-sectional transects where they record the depth of channels from known levels above high water levels. They also recommended that managers measure the channel's width-todepth ratios with a goal of reducing the width and increasing the depth of stream channels.

Rangeland riparian vegetation communities are currently being inventoried. Many of these inventories include indicators or descriptions of geological and hydrological (water-based) processes that can be used by managers to predict which plants should occur within a particular stream section. For example, Weixelman and coauthors in 1997 reported a USFS technique that used depth to water tables, and soil textural classes. Many techniques rely heavily on the underlying geology, shape, slopes and aspects of the watershed from ridge top to ridge top and including the upstream system.

Once the possible vegetation communities are known for a riparian system, monitoring of changes 
in communities and linking those vegetation changes to changes in the stream system can be conducted. The USFS, through Winward's 2000 technical report, offered a quantitative approach for monitoring riparian plant communities over time, thus providing a mechanism to track trends in riparian communities. These include a combination of vegetation measurements such as cross-section composition (the plant species and their proportions along a transect that crosses the stream), greenline composition (the plant species and their proportions along the strip of vegetation that remains green throughout the summer in arid environments), and woody species regeneration methods (quantities of shrub seedlings and sprouts in the riparian area). Each of these methods requires that the observer have knowledge about changes in plant communities after disturbances like floods or heavy animal use and about the soil and water requirements for each plant species within that community. These techniques can be easily linked with Harrellson and coauthors techniques for monitoring changes in the stream's physical measurements.

These methods tended to be labor intensive, but several agencies desired techniques to aid them in evaluating quickly larger proportions of stream systems. A multiple agency team led by Prichard in 1998 published a users guide for assessing proper functioning condition of streams. This technique provides a qualitative evaluation of vegetation, landform and sticks and logs present in the river and along the streambank to (1) dissipate stream energy during high flows, (2) filter and capture soils to aid floodplain development, (3) improve flood water retention and ground-water recharge, (4) develop plant roots that stabilize stream banks against excessive erosion, (5) develop habitat for fish and wildlife, and (6) support biodiversity. The procedure uses a scorecard approach with 17 statements in 3 categories hydrology, vegetation and erosion/deposition to determine a functional rating (proper functioning condition, functional-at risk, nonfunctional, or unknown) and speculate on the trend over time for functional-at risk (upward, downward, or not apparent) should that category be selected in the rating.

National and Regional Evaluations - Globally, nations are advocating accountability for how humans are managing natural resources. International summits have advocated for evaluations of sustainable development among nations. Several working groups have begun to develop criteria and indicators for evaluating sustainable use of natural resources. For rangelands in the U.S.A., the Sustainable Rangelands Roundtable was formed to develop an initial set of criteria and indicators for rangeland sustainability (see Bartlett and other 2003). They developed five criteria of which three are ecological (plant and animal, soil and water, and productivity) and two are social and economic, and legal and institutional criteria. This is an attempt to include human needs into the evaluations of sustainable uses of resources.

In a separate national evaluation, the Heinz Foundation in 2002 produced a national evaluation of lands in the U.S.A. Rangelands are represented in this report by the section on grasslands and shrublands. Each section has indicators with current national or regional information describing the size and extent, the chemical and physical conditions, the biological conditions and the human uses.

In 2003, the NRCS implemented the National Resources Inventory Rangeland Field Study on private, state and tribal lands throughout the western U.S.A. Rangelands have been a minor component of previous inventories, but this effort reflects a renewed commitment to include a broad set of ecosystem functions in the inventory (see Spaeth and coauthors 2003).

As evaluations expand to larger spatial dimensions, the resolution and usefulness in the management of any particular area of ground becomes less important. We begin to look for trends across regions. Many people do not grasp the importance of evaluations at this level, but such evaluations can provide a means for prioritizing where, as a nation, we spend money to improve rangelands and preserve the lands for sustainable uses.

\section{Future Rangeland Evaluations}

Although remote sensing technology has been with us for the last 25 years, we believe that it is only recently become a useful tool and one that shows additional promise as we learn how to apply it appropriately and how to link it to land-based techniques in a cost-effective manner.

During the last 25 years, Landsat and AVHRR (Advanced Very High Resolution Radiometer) 
satellite technologies have provided insights into changes in land uses and major changes in vegetation. Palmer and Fortescue in 2003 described how remote sensing analysts used images from different years to detect changes from forest to pasturelands, from grasslands to woodlands and from vegetated lands to denuded lands as in desertification. Given the technology and its reliance on the reflectance of large areas of land, $30 \mathrm{~m}^{2}$ or more, our estimates of these changes are still relatively unreliable without extensive ground-based data for verification, especially in sparsely vegetated ecosystems.

Remote sensing technology combined with Geographic Information Systems (GIS) are providing us tools to examine how rangelands that are isolated by development, invasive species or changes in land uses may impact wildlife species that require large expanses of undeveloped lands. Pyke and Knick in 2003 discussed how these tools could provide us a mechanism for prioritizing our restoration and improvement efforts. Using GIS technology, we can simultaneously evaluate soils, potential productivity, climate, and vegetation communities. This improves our ability to develop predictive models useful in designing effective restoration plans and reconnecting fragmented habitats.

Future national and international policies may dictate a need for new rangeland evaluations. One function of rangelands that is poised for incorporation in evaluations is carbon storage. If nations begin to negotiate carbon credits, as is currently being discussed, it is within the realm of possibility that management changes will need to be evaluated relative to their impact on carbon storage. This may lead to new techniques for monitoring carbon within ecosystems.

Rest assured, changes in rangeland evaluations will continue. We should not halt or resist this progress, but rather should enthusiastically encourage new developments and thoroughly test them. That said, as evaluation techniques change, we should strive to incorporate and use them along with the older techniques to provide some period of continuity as we adjust to improved methods. We can apply a useful approach from the soil science community. That approach is the understanding that as we learn more and improve methods, we will change how we measure and evaluate rangelands. Thus each new approach becomes a new approxi- mation or version of our knowledge of rangeland evaluations. We should anticipate at least as many new developments in the next 25 years as we had in the last 25 years.

About the Authors: David Pyke is a Research Rangeland Ecologist, USDI, U.S. Geological Survey, Forest \& Rangeland Ecosystem Science Center, Corvallis Research Group, 3200 SW Jefferson Way, Corvallis, OR 97331. Jeffrey Herrick is a Research Soil Scientist, USDA, Agricultural Research Service, Jornada Experimental Range, MSC3JER, Box 30003, New Mexico State University, Las Cruces, NM 88003.

\section{References}

Bartlett, E.T., K.A. Maczko, and J.E. Mitchell. 2003. Ecological, economic and social indicators: assessing rangeland sustainability. Pages 1897-1908, IN: Allsopp N., A.R. Palmer, S.J. Milton, K.P. Kirkman, G.I.H. Kerley \& C.R. Hurt (eds) Proceedings of the VII ${ }^{\text {th }}$ International Rangelands Congress, $26^{\text {th }}$ July-1 $1^{\text {st }}$ August 2003, Durban, South Africa. Document Transformation Technologies, Irene, South Africa.

Bestelmeyer, B.T., J.R. Brown, K.M. Havstad, R. Alexander, G. Chavez, and J.E. Herrick. 2003. Development and use of state and transition models for rangeland management. J. Range Manage. 56:114-126.

Briske, D. D., S. D. Fuhlendorf, and F. E. Smeins. 2003. Vegetation dynamics on rangelands: a critique of the current paradigms. J. Appl. Ecol. 40:601-614.

Chaney, E., W. Elmore, and W.S. Platts. 1993. Managing change: livestock grazing on western riparian areas. Environmental Protection Agency Region 8, Denver, Colo.

Daubenmire, R. 1966. Vegetation: identification of typal communities. Science 151:291-298.

Dyksterhuis, E.J. 1949. Condition and management of rangeland based on quantitative ecology. J. Range Manage. 2:104-115.

Elmore, W., and B. Kauffman. 1994. Riparian and watershed systems: degradation and restoration. p. 212-231. In: M. Vavra, W.A. Laycock, and R.D. Pieper (eds) Ecological implications of livestock herbivory in the west. Society for Range Management, Denver, Colo.

Friedel, M.H. 1991. Range condition assessment and the concept of thresholds: A viewpoint. J. Range Manage. 44:422426.

Harrellson, C.C., C.L. Rawlins, and J.P. Potyondy. 1994. Stream channel reference sites: an illustrated guide to field technique. USDA, For. Serv., Rocky Mtn. For. and Range Exper. Stn. Gen. Tech. Rep. RM-245. Fort Collins, Colo.

Heady, H.F. 1975. Rangeland management. McGraw-Hill, San Francisco, Calif. 
Heinz Foundation (The H. John Heinz III Foundation for Science, Economics and the Environment). 2002. The state of the nation's ecosystems. Cambridge Univ. Press, New York N.Y.

Laycock, W.A. 1991. Stable states and thresholds of range condition on North American rangelands: A viewpoint. J. Range Manage. 44:427-433.

National Research Council. 1994. Rangeland health: new methods to inventory, classify and monitor rangelands. National Academy Press, Washington D.C.

NRCS (Natural Resources Conservation Service). 1997. National range and pasture handbook. USDA-NRCS, Washington, D.C.

Palmer, A.R. and A. Fortescue. 2003. Remote sensing and change detection in rangelands. Pages 675-680, In: Allsopp N., A.R. Palmer, S.J. Milton, K.P. Kirkman, G.I.H. Kerley \& C.R. Hurt (eds) Proceedings of the VII ${ }^{\text {th }}$ International Rangelands Congress, 26 ${ }^{\text {th }}$ July- $1^{\text {st }}$ August 2003, Durban, South Africa. Document Transformation Technologies, Irene, South Africa.

Pellant, M., P. Shaver, D.A. Pyke, and J.E. Herrick. 2000. Interpreting indicators of rangeland health, version 3. USDI BLM, National Science and Technology Center, Technical Reference 1734-6, Denver, Colo.

Prichard, D., J. Anderson, C. Correll, J. Fogg, K. Gebhardt, R. Krapf, S. Leonard, B. Mitchell, and J. Staats. 1998. Riparian area managment: a user guide to assessing proper functioning condition and the supporting science for lotic areas. U.S. Dept. Int., Bur. Land Manage. Tech Ref. TR-1737-15. National Appl. Res. Sci. Cntr., Denver, Colo.

Pyke, D.A., J.E. Herrick, P. Shaver, and M. Pellant. 2002. Rangeland health attributes and indicators for qualitative assessment. J. Range Manage. 55:584-597.

Pyke, D.A. and S.T. Knick. 2003. Plant invaders, global change, and landscape restoration. Pp 278-288 IN: Allsopp N., A.R. Palmer, S.J. Milton, K.P. Kirkman, G.I.H. Kerley \& C.R. Hurt (eds) Proceedings of the $\mathrm{VI}^{\text {th }}$ International Rangelands Congress, $26^{\text {th }}$ July- $1^{\text {st }}$ August 2003, Durban, South Africa. Document Transformation Technologies, Irene South Africa

SCS (Soil Conservation Service). 1976. National range handbook. Washington, D.C.

Spaeth, K.E., F.B. Pierson, J.E. Herrick, P.L. Shaver, D.A. Pyke, M. Pellant, D. Thompson, and B. Dayton. 2003. New proposed national resources inventory protocols on nonfederal rangelands. J. Soil Water Conserv. 58:18-21.

Stoddart, L.A., A.D. Smith, and T.W. Box. 1975. Range management, $3^{\text {rd }}$ Edition. McGraw-Hill, San Francisco, Calif.

Stringham, T.K., W.C. Krueger, and P.L. Shaver. 2003. State and transition modeling: an ecological process approach. J. Range Manage. 56:106-113.
Task Group on Unity in Concepts and Terminology (Society for Range Management). 1995. New concepts for assessment of rangeland condition. J. Range Manage. 48:271-282.

Tongway, D.J. 1994. Rangeland soil condition assessment manual. CSIRO, Melbourne.

Tongway, D., and Hindley N. 2000. Assessing and monitoring desertification with soil indicators. p. 89-98. In: Arnalds, and S. Archer (eds), Rangeland desertification. Kluwer Academic, Boston, Mass.

Westoby, M., B. Walker, and I. Noy-Meir. 1989. Opportunistic management for rangelands not at equilibrium. J. Range Manage. 42:266-274.

Weixelman, D.A., D.C. Zamudio, K.A. Zamudio, and R.J. Tausch. 1997. Classifying ecological types and evaluating site degradation. J. Range Manage. 50:315-321.

Winward, A. H. 2000. Monitoring the vegetation resources in riparian areas. USDA Forest Service, Rocky Mnt. Res. Stn. Gen. Tech. Rep. RMRS-GTR-47. Ogden, Utah. 